\title{
Development of the Hatagawa Fault Zone clarified by geological and geochronological studies
}

\author{
Tomoaki Tomita ${ }^{1}$, Tomoyuki Ohtani ${ }^{2}$, Norio Shigematsu ${ }^{2}$, Hidemi Tanaka ${ }^{3}$, Koichiro Fujimoto ${ }^{2}$, \\ Yoji Kobayashi ${ }^{1}$, Yukari Miyashita ${ }^{2}$, and Kentaro Omura ${ }^{4}$ \\ ${ }^{1}$ Geoscience Institute, University of Tsukuba, Tsukuba, Ibaraki 305-8571, Japan \\ ${ }^{2}$ Geological Survey of Japan, AIST, Tsukuba, Ibaraki 305-8567, Japan \\ ${ }^{3}$ Department of Earth and Planetary Sciences, University of Tokyo, Hongo, Tokyo 113-0033, Japan \\ ${ }^{4}$ National Research Institute for Earth Science and Disaster Prevention, Tsukuba, Ibaraki 305-0006, Japan
}

(Received January 17, 2002; Revised September 20, 2002; Accepted September 24, 2002)

\begin{abstract}
The occurrence of mylonite and cataclasite, mineral assemblages of cataclasite, and the K-Ar ages of surrounding granitic rocks and dikes were studied to examine the possibility that the Hatagawa Fault Zone (HFZ), NE Japan was experienced under the conditions of the brittle-plastic transition. The Hatagawa Fault Zone is divided into three structural settings: mylonite zones with a sinistral sense of shear and a maximum thickness of $1 \mathrm{~km}$, a cataclasite zone with a maximum thickness of about $100 \mathrm{~m}$, and locally and sporadically developed small-scale shear zones. Occurrence of epidote and chlorite, lack of montmorillonite in cataclasite, and the coexistence of cataclasite and limestone mylonite suggest that the cataclasite was deformed at temperatures higher than $220^{\circ} \mathrm{C}$. Crush zones in the mylonite near the cataclasite zone were recognized in one outcrop; they have a structure concordant with the surrounding mylonite and some fragments in them are dragged plastically. Granodiorite porphyry dikes near the HFZ intruding into cataclasite and mylonite with a sinistral sense of shear exhibit no deformational features. K-Ar ages of hornblende from host granitic rocks and from one granodiorite porphyry dike are $126 \pm 6$ to $95.7 \pm 4.8$ and $98.1 \pm 2.5 \mathrm{Ma}$, respectively. These indicate that the fault activity gradually changed from mylonitization to cataclasis within 28 m.y., and suggest that the HFZ underwent a brittle-plastic transition during its activity.
\end{abstract}

\section{Introduction}

It has been considered that the main ruptures of large intraplate earthquakes start in the brittle-plastic transition zone, as their hypocenters are generally located in the deepest region of the seismogenic zone (Sibson, 1989). Seismic slips have been reported to occur along deep extensions of mainshock fault planes before large earthquakes (Thatcher, 1976; Linde et al., 1988; Iio et al., 2001). These suggest the significance of plastic flow in the brittle-plastic transition zone for the generation of large earthquakes.

The Hatagawa Fault Zone (HFZ), NE Japan consists of various kinds of fault rocks such as cataclasite and mylonite (Shigematsu and Yamagishi, 2002). Recent studies have clarified the conditions during the development of these fault rocks. Takagi et al. (2000) and Shigematsu et al. (2001) revealed that some of the small-scale shear zones were formed under conditions of brittle-plastic transition. Shigematsu and Yamagishi (2002) revealed that two types of quartz microstructures, microstructures $\mathrm{A}$ and $\mathrm{B}$, are observed in the mylonite along the HFZ. Analyses of the lattice preferred orientation of the quartz c-axis, feldspar microstructures, and feldspar compositions suggest that temperature difference was the key factor in the two different microstructures of quartz. As determined by a two-feldspar geothermometer,

Copy right (c) The Society of Geomagnetism and Earth, Planetary and Space Sciences (SGEPSS); The Seismological Society of Japan; The Volcanological Society of Japan; The Geodetic Society of Japan; The Japanese Society for Planetary Sciences. the syn-deformation temperature in the quartz microstructure A mylonite is 260 to $310^{\circ} \mathrm{C}$, while that in quartz microstructure $\mathrm{B}$ mylonite is 310 to $450^{\circ} \mathrm{C}$. Analysis of the $\mathrm{HFZ}$ could provide clues about the occurrence of earthquakes in brittleplastic transition zones. In this study, we report on the occurrence of mylonite and cataclasite, the mineral assemblages of cataclasite, and the K-Ar ages of surrounding granitic rocks and dikes to examine the possibility that the activity of the HFZ occurred under the conditions of a brittle-plastic transition.

\section{Hatagawa Fault Zone}

The HFZ is located at the eastern margin of the Abukuma Mountains, NE Japan (Fig. 1), and trends in the NNWSSE direction, parallel to the Futaba Fault Zone (Watanabe et al., 1953; Sendo, 1958). Magnetite-free Cretaceous granitic rocks are distributed mainly to the west of the HFZ (the Abukuma belt), while the magnetite-bearing Cretaceous granitic rocks are distributed mainly to its east (the Southern Kitakami belt); the HFZ separates these two belts (Kubo and Yamamoto, 1990). Metamorphic rocks and limestone are sparsely distributed along the HFZ. The total displacement of the HFZ was estimated from the displacement of the metamorphic rocks to be about $60 \mathrm{~km}$ (Otsuki and Ehiro, 1992). The Neogene formation is likewise displaced by faults accompanied with fault gouges and fault breccia, but this displacement is beyond the scope of this paper, having been 


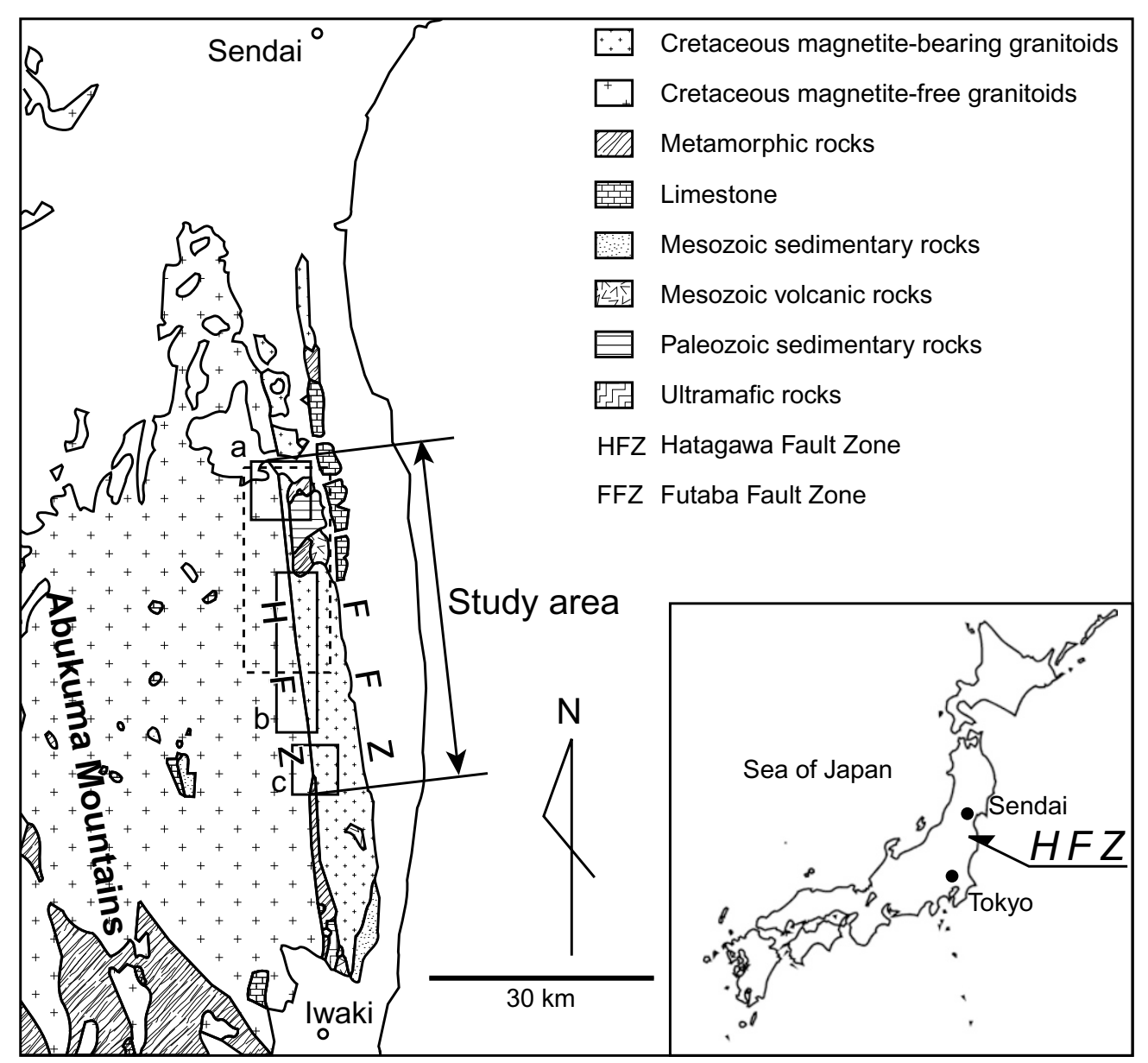

Fig. 1. Regional geological map of the Hatagawa Fault Zone, NE Japan (Simplified from Geological Survey of Japan, 1992). Black frames a, b and c are shown in Fig. 2. The area enclosed by the broken line is shown in Fig. 6.

formed at shallower depths than the brittle-plastic transition zone.

The HFZ mainly consists of three structural settings (Fig. 2): mylonite zones with a sinistral sense of shear, a cataclasite zone, and small-scale shear zones. Mylonite zones with a sinistral sense of shear are heterogeneously distributed with a maximum thickness of $1 \mathrm{~km}$ along the HFZ. The foliation strikes N-S to NE-SW and dips subvertically; the stretching lineation is subhorizontal (Fig. 2). Quartz microstructures in the mylonite zones can be subdivided into two groups, microstructures A and B (Figs. 3(a) and 3(b)) (Shigematsu and Yamagishi, 2002). Microstructure A displays core and mantle structures (White, 1976), in which coarse ribbon grains are extremely elongated and surrounded by fine equant grains. In microstructure $\mathrm{B}$, the shapes of grain boundaries are sutured, and the aspect ratios of grains are smaller than in microstructure A. In the mylonite with quartz microstructure $\mathrm{A}$, quartz c-axis fabric shows type I crossed girdle, and K-feldspar porphyroclasts are often fragmented. In the mylonite with quartz microstructure B, quartz c-axis fabric shows Y-maximum or type II crossed girdle. Evidence for the replacement of K-feldspar porphyroclast by myrmekite can also be observed in microstructure B mylonite; some K-feldspar porphyroclasts show undulatory extinction and have an elongated ribbon shape. Myrmekite has never been found in mylonite with quartz microstructure A.
Along the Ukedo River, mylonite with microstructure A is distributed closer to the cataclasite zone than that with microstructure B (Shigematsu and Yamagishi, 2002).

A conspicuous cataclasite zone with a maximum thickness of about $100 \mathrm{~m}$ extends continuously in the HFZ for at least $40 \mathrm{~km}$ (Fig. 2). In some places the cataclasite exhibits foliation that is subparallel to the general trend of the cataclasite zone. It also contains limestone mylonites. Fragments in cataclasite consist of both mylonite and undeformed granite within the matrix of altered minerals (Fig. 3(c)). X-ray powder diffraction revealed that these altered minerals consist mainly of chlorite, calcite, and epidote, but not montmorillonite (Table 1). In these samples, biotite and hornblende have either disappeared or are rare. Prehnite was detected in a mylonite near the cataclasite zone.

Small-scale shear zones from millimeters to several meters in thickness are locally and sporadically developed in the granitic rocks along the HFZ (Shigematsu, 1999; Shigematsu and Tanaka, 2000; Takagi et al. 2000). The surrounding granitic rocks are undeformed or show a mylonite microstructure with a sinistral sense of shear, suggesting that the small-scale shear zones were formed after the mylonite zone with a sinistral sense of shear. These small-scale shear zones usually form NNW-SSE trending zones along the HFZ. For example, in the area pictured in Fig. 2(b) they form in a region about $1 \mathrm{~km}$ wide, west of the HFZ. 


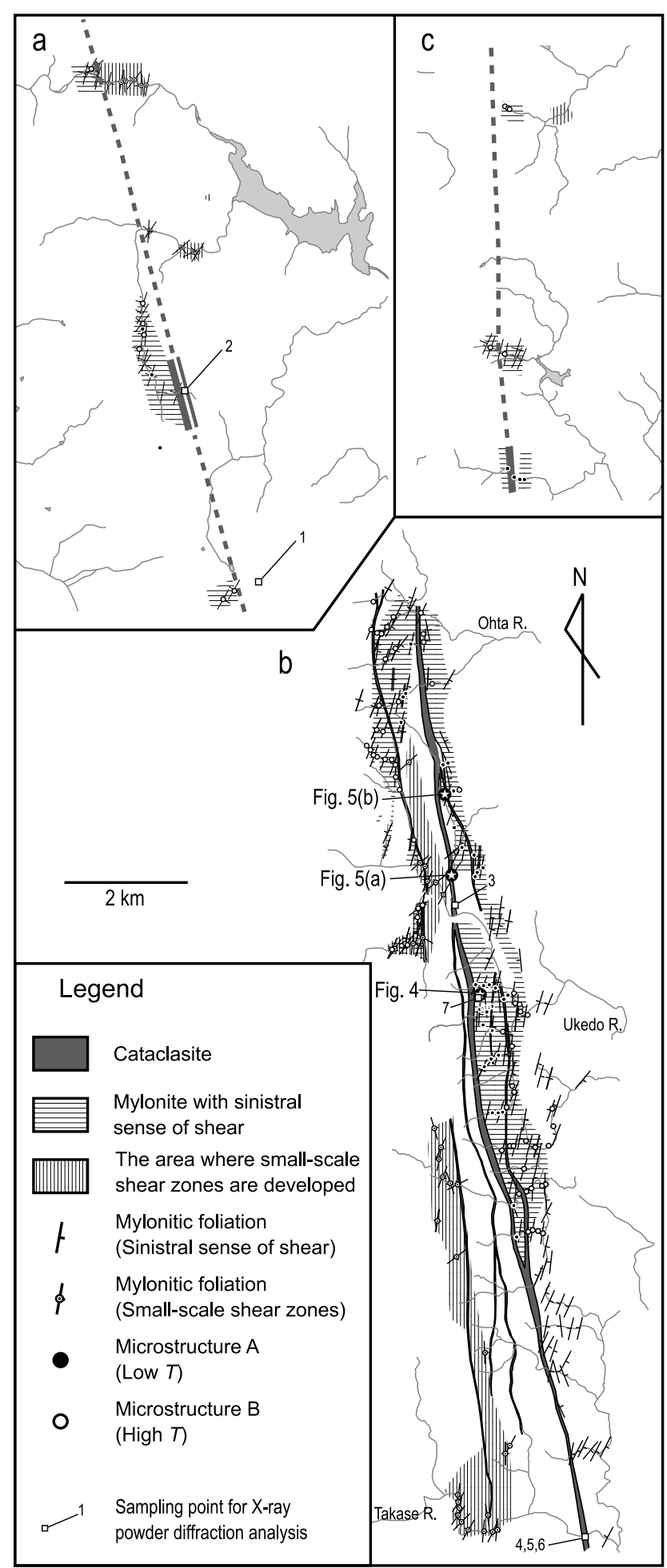

Fig. 2. Distribution of cataclasite, mylonite with sinistral sense of shear, and small-scale shear zones, and sampling points for X-ray powder diffraction analysis. The locations of a, b and $\mathrm{c}$ are shown in Fig. 1.

The shear zones form conjugate sets; for example, one of the sets has a NNE-SSW to NE-SW orientation with a dextral sense of shear, while the other has an EW to ESEWNW orientation with a sinistral sense of shear, a phenomenon suggesting that the maximum principal stress direction was orientated almost E-W (Shigematsu and Tanaka, 2000). The most strongly deformed parts of the small-scale
Table 1. Mineral distribution of the cataclasite and mylonite along the cataclasite zone of the Hatagawa Fault Zone.

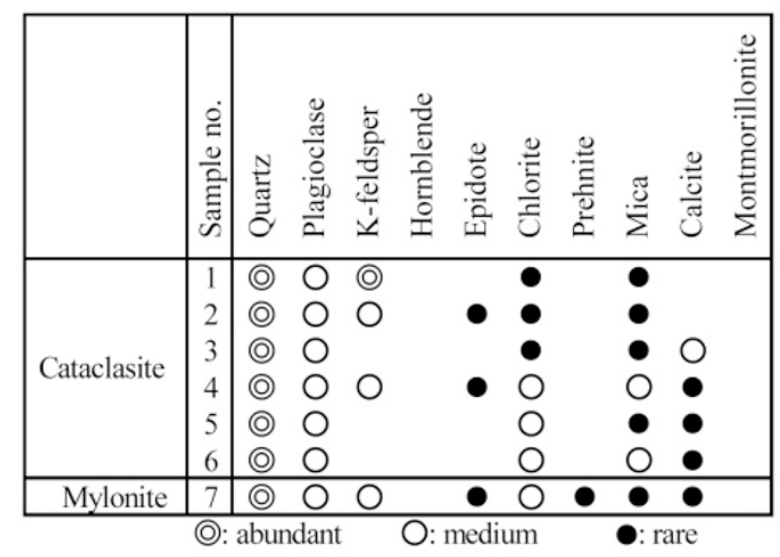

shear zones usually consist of ultramylonite and occasionally of pseudotachylyte (Takagi et al., 2000). The ultramylonite shows evidence of plastic deformation of quartz and feldspar by dislocation-related processes (Shigematsu, 1999; Shigematsu and Tanaka, 2000). Some of the smallscale shear zones in the HFZ include crush zones parallel to the shear zone boundary. These crush zones are developed where plastic deformation was concentrated; they were crushed during the plastic deformation, under the condition of a brittle-plastic transition (Shigematsu et al., 2001).

In one outcrop near the cataclasite zone, crush zones were found in strongly deformed mylonite zones with microstructure A (Fig. 4(a)). This outcrop is located $200 \mathrm{~m}$ east from the cataclasite zone. A quartz porphyry dike is intruded into granodiorite, and both have undergone plastic deformation. We categorized the deformed granodiorite into three types based on the development of mylonitic foliation. Although deformation generally becomes stronger toward the western part in this outcrop, deformation is heterogeneous and deformation-localized zones are developed in moderately and strongly deformed granodiorites. The deformationlocalized zones are a thickness of millimeter to centimeter scale. Foliation of deformation-localized zones is subparallel to that of deformed granodiorite and quartz porphyry. The crush zones are developed in the deformation-localized zones (Fig. 4(b)) and are parallel to the foliation of the surrounding deformed granodiorite. Fragments of mylonite are rotated in the crush zones; some fragments in crush zones are dragged plastically (Fig. 4(c)). Epidote and chlorite are included in the crush zones matrices. The deformation microstructures of crush zones in mylonite with microstructure A are similar to those in small-scale shear zones.

Quartz porphyry dikes, aplite veins, and granodiorite porphyry dikes are distributed plentifully along the HFZ. Figure 5 indicates the relationship between quartz porphyry, granodiorite porphyry, mylonitized granitic rocks, and cataclasite in the HFZ. The quartz porphyry dikes near the HFZ exhibit plastic deformational features, as do the surrounding host granitic rocks. The boundaries of quartz porphyry are subparallel to foliation of mylonite of granitic rocks (Figs. 4(a) and 5(a)). On the other hand, the granodiorite porphyry dikes show no plastic deformational features, 
a

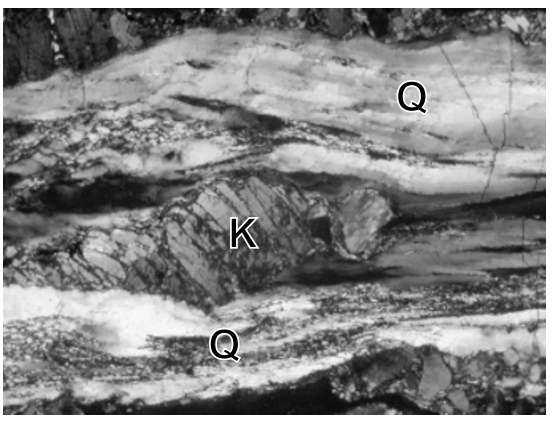

b

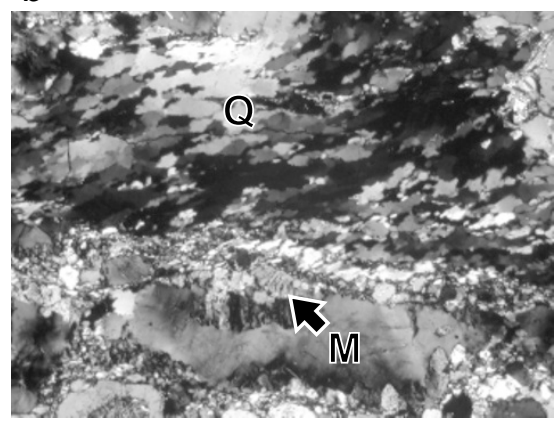

C

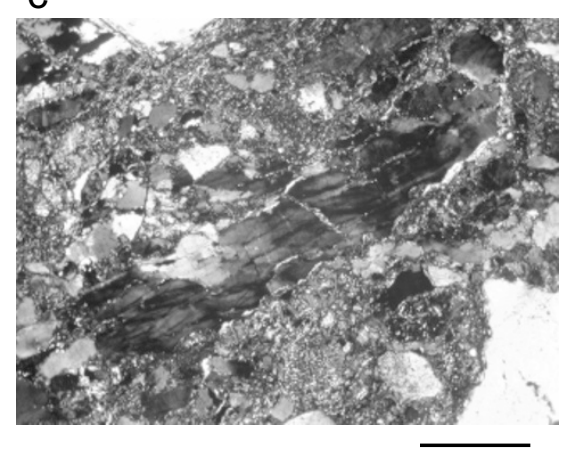

Fig. 3. Microstructures of the fault rocks from the Hatagawa Fault Zone. a) Mylonite with microstructure A. Q: Extremely elongated quartz grains. K: Fragmented K-feldspar. b) Mylonite with microstructure B. Q: Slightly elongated quartz grains. M: Myrmekite. c) Cataclasite with fragments of mylonite. Scale bar is $0.5 \mathrm{~mm}$.

\section{a}

Mylonitic foliation of deformed granodiorite

F Foliation of deformation localized zone

F Boundary of granodiorite and quartz porphyry

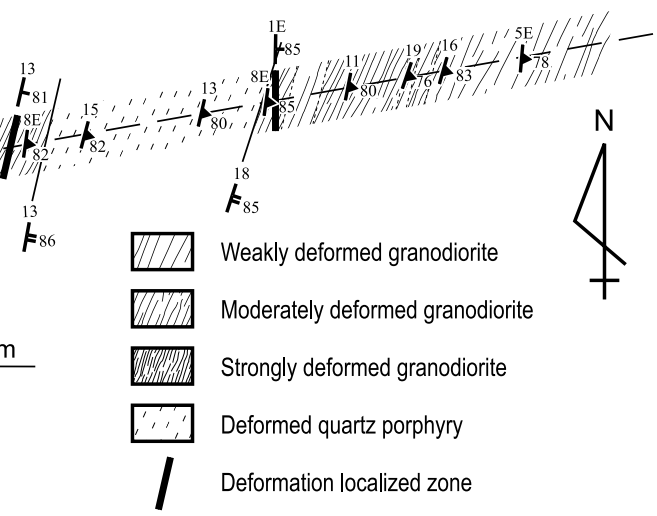

b

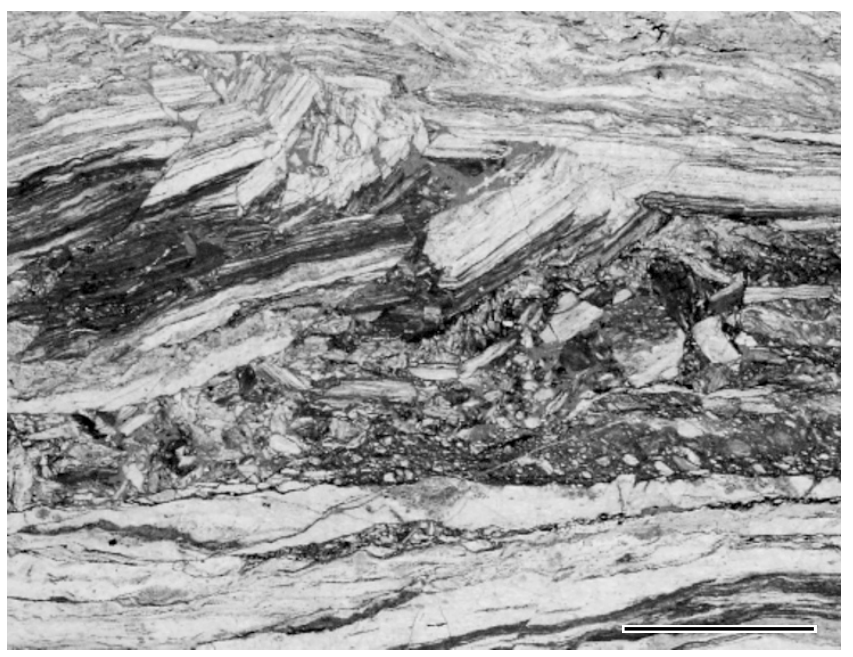

C

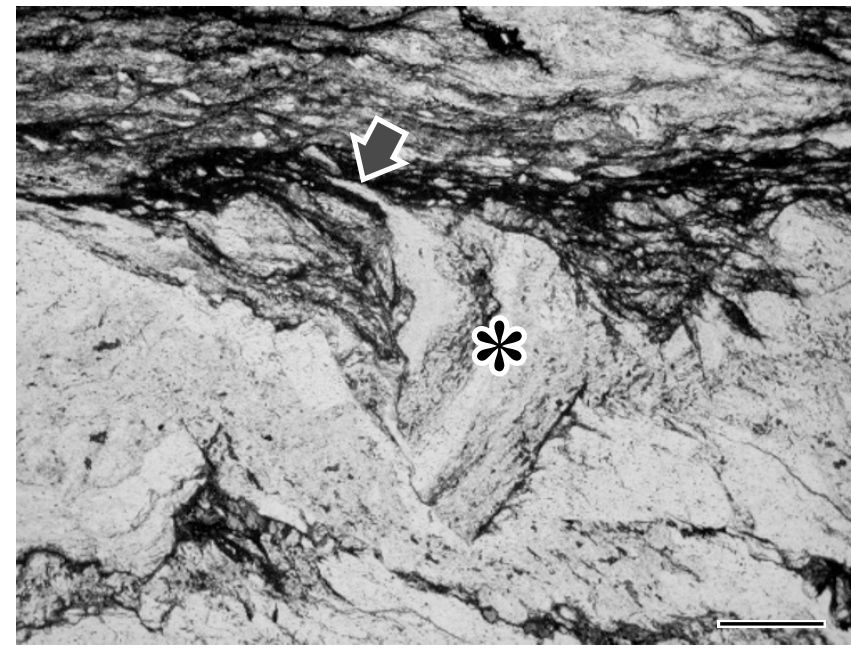

Fig. 4. A crush zone in a deformation-localized zone in mylonite with microstructure A near the cataclasite zone. Location is shown in Fig. 2. a) Lithological map of an outcrop of mylonite with microstructure A including deformation-localized zones. b) A crush zone in a deformation-localized zone developed parallel to the mylonitic foliation. Scale bar is $5 \mathrm{~mm}$. c) A fragment of mylonite (asterisk) is dragged plastically (arrow) in a crush zone. Scale bar is $1 \mathrm{~mm}$.

and intrude into both the mylonite and the cataclasite zones along the HFZ (Fig. 5(b)). Foliation of cataclasite is subparallel to the general trend of the cataclasite zone and oblique to foliation in mylonite. The aplite veins near the HFZ ex- hibit plastic deformational features, as do the surrounding host granitic rocks. 


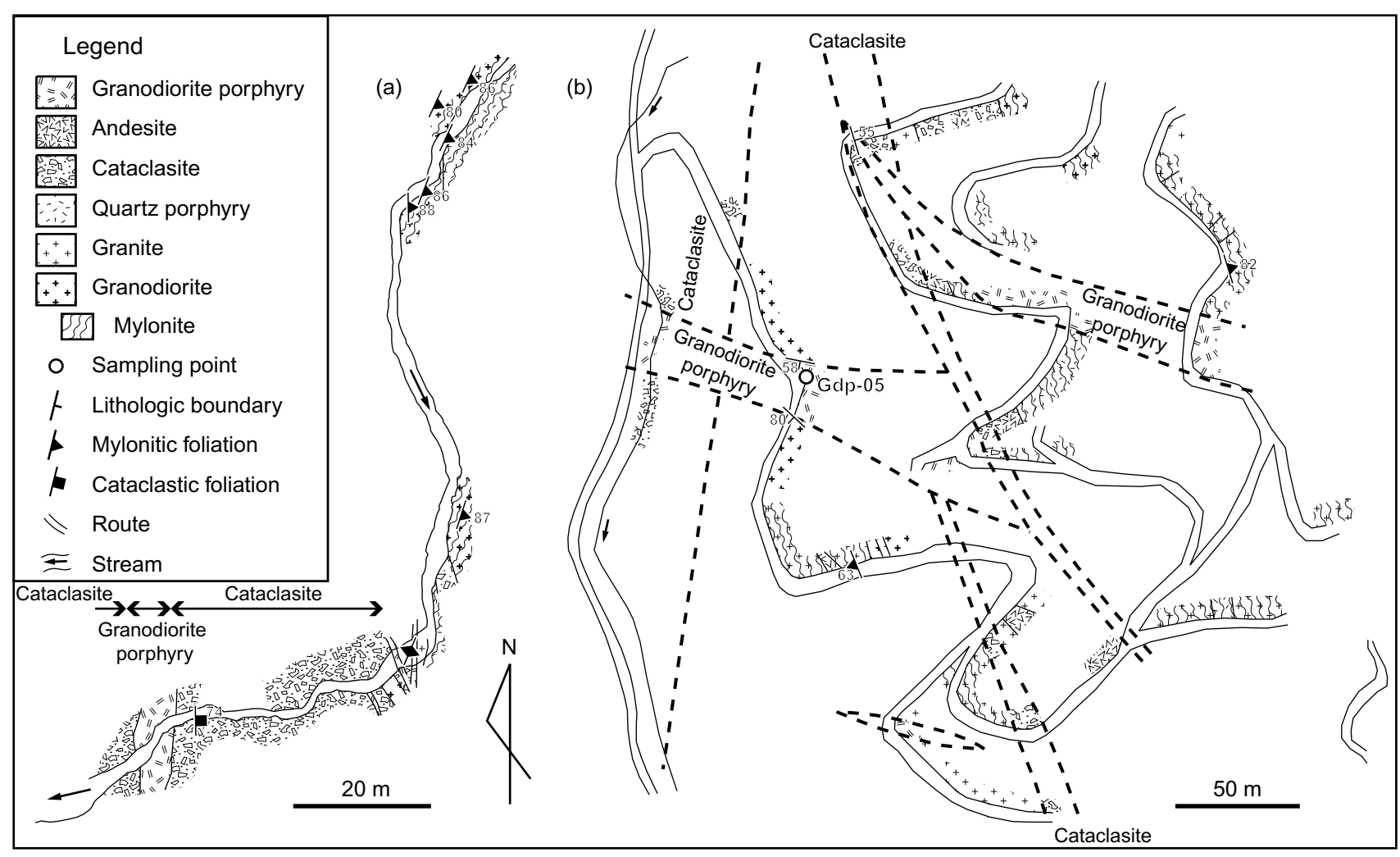

Fig. 5. Route maps along the cataclasite zone of the Hatagawa Fault Zone indicate the relationship among granodiorite porphyry dikes, quartz porphyry dikes, and fault rocks. Quartz porphyry dikes are mylonitized with host granitic rocks. Granodiorite porphyry dikes are undeformed. In (b), a cataclasite zone which terminates the distribution of the granodiorite porphyry dike contains fault gouge, indicating that this cataclasite zone reworked and displaced the dike in Neogene. Locations of these route maps are shown in Fig. 2.

\section{Geochronologic Procedure and Results}

$\mathrm{K}$-Ar dating was performed for 22 samples from undeformed granitic rocks and dikes along the HFZ to provide a geochronological constraint on mylonite and cataclasite formation (Table 2 and Fig. 6). All data were calculated using decay constants recommended by Steiger and Jäger (1977).

The K-Ar ages of whole rock from granodiorite porphyry dikes are younger than those of hornblende from the same dikes (e.g. Gdp-06a and Gdp-06b). The K-Ar ages of whole rock from aplite veins are also younger than that of biotite. There is a possibility that the hydrothermal alteration of dikes is responsible for these differences in K-Ar ages. Therefore, we concluded that the K-Ar ages of whole rock do not indicate the age of intrusions.

The K-Ar ages of granite and granodiorite on eastern and western side of the HFZ show a range of $126 \pm 6$ to $97.4 \pm 4.9$ $\mathrm{Ma}$ and $110 \pm 5$ to $95.7 \pm 4.8 \mathrm{Ma}$, respectively. We cannot recognize the difference of $\mathrm{K}$-Ar ages between granitic rocks on eastern and western side of the HFZ as reported by Shibata and Uchiumi (1983) and Kubo and Yamamoto (1990). The $\mathrm{K}-\mathrm{Ar}$ age of biotite from an aplite is $113 \pm 6 \mathrm{Ma}$. The K-Ar ages of hornblende, biotite, and $\mathrm{K}$-feldspar from dikes range from $114 \pm 6$ to $96.8 \pm 4.8 \mathrm{Ma}$, within the range of $\mathrm{K}$-Ar ages of the host granitic rocks. The K-Ar age of hornblende from an undeformed granodiorite porphyry dike intruding into cataclasite, Gdp-05, is $98.1 \pm 2.5 \mathrm{Ma}$.

The closure temperature of hornblende is $510 \pm 30^{\circ} \mathrm{C}$ and that of biotite is $300 \pm 50^{\circ} \mathrm{C}$ (Dodson and McClellandBrown, 1985). On the other hand, the results from a pluton of granodiorite (GdW-01, GdW-02, and GdW-GSJ) show that the results of hornblende from some samples are younger than that of biotite from another sample. Samples that contain older biotite (GdW-01 and GdW-02) are located at the margin of the pluton, while the sample of younger biotite (GdW-GSJ) is located in the center of the pluton. This difference of K-Ar ages can be considered to reflect different histories of cooling at the margin and the center of the pluton.

\section{Discussion}

The relation between dike intrusions and three structural settings was revealed along the HFZ (Fig. 5). Quartz porphyry dikes and aplite veins are deformed with host granitic rocks, while granodiorite porphyry dikes exhibit no deformational features intruding into the mylonite and cataclasite zones. Cataclasite includes fragments of mylonites (Fig. 3(c)), suggesting that the mylonitization occurred prior to cataclasis. The oldest K-Ar age of hornblende from granitic rocks (GdK-GSJ) is $126 \pm 6 \mathrm{Ma}$, while the $\mathrm{K}-\mathrm{Ar}$ age from one of the undeformed granodiorite porphyry dikes (Gdp-05) is $98.1 \pm 2.5 \mathrm{Ma}$ (Table 2). From these data we deduced the following history of the HFZ.

Granite and granodiorite intruded multiply after $126 \pm 6$ Ma. The quartz porphyry dikes and aplite veins intruded next. The fault activity of the HFZ started as a mylonitization with a sinistral sense of shear after the intrusion of these dikes and aplite veins. Later, the fault activity changed from mylonitization to cataclasis. 


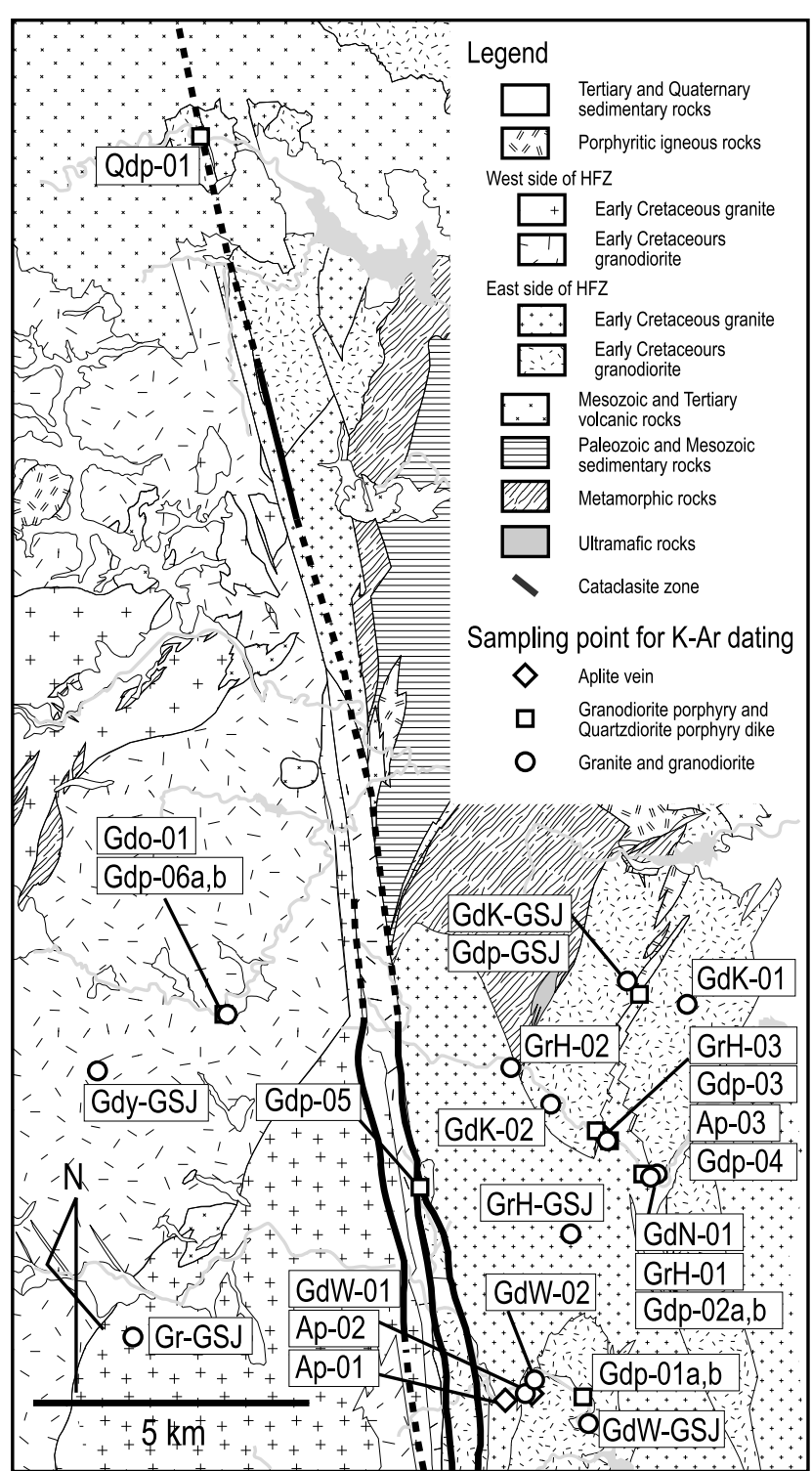

Fig. 6. Simplified geological map along the Hatagawa Fault Zone and locations of samples for K-Ar dating. Compiled from Kubo et al. (1990) and Yanagisawa et al. (1996). Qdp, Gdp, and Ap show quartz diorite porphyry, granodiorite porphyry, and aplite, respectively. Grx and Gdx show samples from granite and granodiorite, respectively; " $x$ " shows name of pluton after Kubo et al. (1990) and Yanagisawa et al. (1996).

The cataclasis of the HFZ had terminated by the intrusion of the undeformed granodiorite porphyry dikes in $98.1 \pm 2.5$ Ma. The duration of the fault activity was limited within 28 m.y. As the ages from all of dikes along the HFZ are within the K-Ar ages of granitic rocks, i.e., between $126 \pm 6$ (GdKGSJ) and $95.7 \pm 6$ (Gdy-GSJ) Ma, the intrusions of dikes and granitic rocks are derived from the same igneous activity. Therefore, the HFZ was active during the igneous activity of the surrounding granitic rocks and dikes. Although faults of the HFZ have displaced the Neogene formation, these differ from the mylonite and cataclasite formations described in this paper; consisting of fault gouges and fault breccia, they are products of shallow faulting rather than the brittleplastic transition. This suggests that the fault activity related to mylonite and cataclasite formations had terminated by $98.1 \pm 2.5 \mathrm{Ma}$, and that the fault was reworked in Neogene, producing fault gouges and fault breccia.

The samples from the cataclasite zone of the HFZ contain calcite, epidote, and chlorite; the mylonite sample near the cataclasite zone contains prehnite; and none of the studied samples contain montmorillonite (Table 1). It is known that epidote, chlorite, and prehnite occur at temperatures higher than $200^{\circ} \mathrm{C}$ and montmorillonite at temperatures lower than $220^{\circ} \mathrm{C}$ in active geothermal fields (Henley and Ellis, 1983). The assemblage of these minerals, therefore, indicates that the cataclasite was formed at temperatures higher than $220^{\circ} \mathrm{C}$. The coexistence of cataclasite and limestone mylonite is consistent with the cataclasite formation at high temperature. From experimental data, the flow stress of calcite is lower than that of quartz under conditions of constant strain rate and temperature (Schmid, 1982). Moreover, the transition of calcite from dominant cataclasis to dominant plasticity is expected at $200^{\circ} \mathrm{C}$ under natural strain rate conditions (Rutter, 1986). Brittle deformation results from low-speed cataclastic flow as well as high-speed ruptures such as earthquakes. Even if granite exhibits brittle deformational features, it does not necessarily offer an evidence of ancient earthquakes. Limestone can, therefore, behave plastically even under conditions in which granitic rocks behave cataclastically.

The conditions of mylonite with microstructure A (Shigematsu and Yamagishi, 2002) are close to that of the cataclasite zone. Moreover, the activity of the HFZ was limited to $28 \mathrm{~m} . \mathrm{y}$. These suggest that the fault activity changed gradually from mylonitization to cataclasis and that the HFZ experienced the brittle-plastic transition during its fault activity. Furthermore, crush zones were found in one outcrop of mylonite with microstructure A near the cataclasite zone (Fig. 4). The structure of the crush zone is concordant with the surrounding mylonite and similar to that in small-scale shear zones formed under the conditions of the brittle-plastic transition; furthermore, some fragments in the crush zones are dragged plastically, indicating that the mylonite with the crush zones had suffered plastic and brittle deformation repeatedly and was formed under the conditions of the brittleplastic transition. Therefore, it can be deduced that the HFZ underwent a brittle-plastic transition during its activity.

\section{Conclusion}

The relationship between the fault rocks and dikes and the K-Ar ages of granitic rocks and dikes together define the development of the Hatagawa Fault Zone (HFZ), NE Japan. The HFZ is divided into three structural settings: mylonite zones with a sinistral sense of shear, cataclasite zones, and small-scale shear zones. Granodiorite porphyry dikes $(98.1 \pm 2.5 \mathrm{Ma})$ exhibit no deformational features intruding into the mylonite and the cataclasite zones, while quartz porphyry dikes and aplite veins were deformed with host granitic rocks. The fault activity of the HFZ, therefore, started as a mylonitization with a sinistral sense of shear after the intrusion of granitic rocks in $126 \pm 6 \mathrm{Ma}$ and terminated as a cataclasis by $98.1 \pm 2.5 \mathrm{Ma}$.

The mineral assemblages of cataclasite indicate that the cataclasite was formed at temperatures higher than $220^{\circ} \mathrm{C}$. This temperature is also close to the conditions of some mylonites along the HFZ (Shigematsu and Yamagishi, 2002). 
Table 2. Results of K-Ar dating. Asterisks represent the data from Kubo et al. (1990). W.R., hb, bt, and K-f indicate whole rock, hornblende, biotite, and potassium feldspar, respectively. Numbering of samples from granite and granodiorite follows the classification of Kubo et al. (1990) and Yanagisawa et al. (1996); for example, in the notation "GdK-01", "Gd" indicates granodiorite, "K" indicates name of pluton, and "01" indicates sample number. Samples from this study were analyzed at Allegheny Technologies Japan, Ltd.

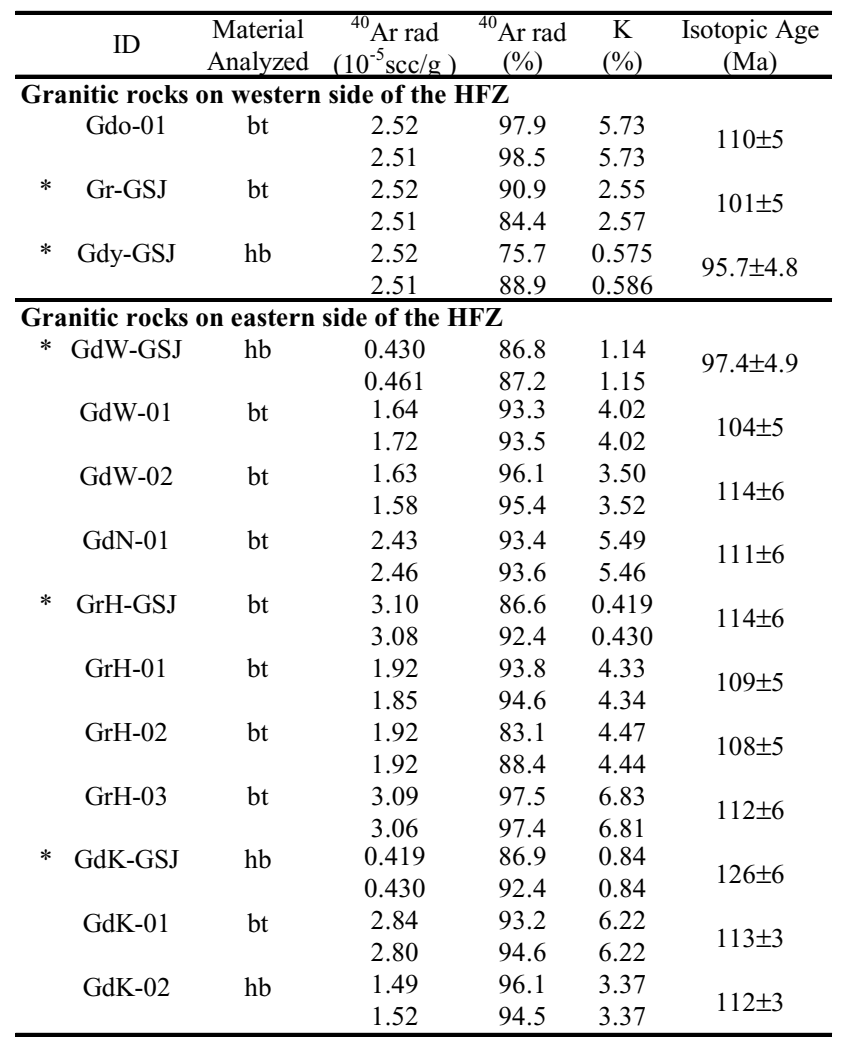

\begin{tabular}{|c|c|c|c|c|c|}
\hline $\begin{array}{c}\text { ID } \\
\text { (Host rock) }\end{array}$ & $\begin{array}{l}\text { Material } \\
\text { Analyzed }\end{array}$ & $\begin{array}{c}{ }^{40} \mathrm{Ar} \mathrm{rad} \\
\left(10^{-5} \mathrm{scc} / \mathrm{g}\right) \\
\end{array}$ & $\begin{array}{c}{ }^{40} \text { Ar rad } \\
(\%)\end{array}$ & $\begin{array}{c}\mathrm{K} \\
(\%) \\
\end{array}$ & $\begin{array}{c}\text { Isotopic Age } \\
(\mathrm{Ma})\end{array}$ \\
\hline \multicolumn{6}{|c|}{ Dikes on western side of the HFZ } \\
\hline \multirow{2}{*}{$\begin{array}{c}\text { Qdp-01 } \\
\text { (Grs) }\end{array}$} & \multirow[t]{2}{*}{ K-f } & 1.16 & 91.9 & 2.94 & \multirow{2}{*}{$96.8 \pm 4.8$} \\
\hline & & 1.11 & 95.6 & 2.93 & \\
\hline \multirow{2}{*}{$\begin{array}{l}\text { Gdp-06a } \\
\text { (Gdo) }\end{array}$} & \multirow[t]{2}{*}{ W.R. } & 1.29 & 97.9 & 3.61 & \multirow{2}{*}{$91.2 \pm 4.6$} \\
\hline & & 1.34 & 97.9 & 3.61 & \\
\hline \multirow{2}{*}{$\begin{array}{l}\text { Gdp-06b } \\
\text { (Gdo) }\end{array}$} & \multirow[t]{2}{*}{$\mathrm{hb}$} & 0.218 & 76.3 & 0.54 & \multirow{2}{*}{$102 \pm 3$} \\
\hline & & 0.221 & 79.5 & 0.54 & \\
\hline \multicolumn{6}{|c|}{ Dikes and aplites on eastern side of the HFZ } \\
\hline \multirow{2}{*}{$\begin{array}{c}\text { Gdp-01a } \\
\text { (GdW) }\end{array}$} & \multirow[t]{2}{*}{ W.R. } & 0.892 & 97.4 & 2.40 & \multirow{2}{*}{$91.0 \pm 4.6$} \\
\hline & & 0.85 & 96.2 & 2.40 & \\
\hline \multirow{2}{*}{$\begin{array}{l}\text { Gdp-01b } \\
\text { (GdW) }\end{array}$} & \multirow[t]{2}{*}{$\mathrm{hb}$} & 1.89 & 93.6 & 4.39 & \multirow{2}{*}{$107 \pm 3$} \\
\hline & & 1.880 & 94.3 & 4.37 & \\
\hline Ap-01 & \multirow[t]{2}{*}{ W.R. } & 1.65 & 98.3 & 4.38 & \multirow{2}{*}{$93.5 \pm 4.7$} \\
\hline$(\mathrm{GdW})$ & & 1.61 & 98.0 & 4.36 & \\
\hline Ap-02 & \multirow[t]{2}{*}{ W.R. } & 1.62 & 98.2 & 4.35 & \multirow{2}{*}{$95.0 \pm 4.8$} \\
\hline$(\mathrm{GdW})$ & & 1.68 & 98.7 & 4.35 & \\
\hline \multirow{2}{*}{$\begin{array}{l}\text { Gdp-02a } \\
(\mathrm{GrH})\end{array}$} & \multirow[t]{2}{*}{ W.R. } & 0.304 & 88.3 & 0.84 & \multirow{2}{*}{$91.7 \pm 4.6$} \\
\hline & & 0.314 & 88.0 & 0.85 & \\
\hline \multirow{2}{*}{$\begin{array}{c}\text { Gdp-02b } \\
(\mathrm{GrH})\end{array}$} & \multirow[t]{2}{*}{$\mathrm{hb}$} & 1.67 & 94.2 & 4.12 & \multirow{2}{*}{$102 \pm 3$} \\
\hline & & 1.70 & 94.6 & 4.11 & \\
\hline \multirow{2}{*}{$\begin{array}{l}\text { Gdp-03 } \\
(\mathrm{GrH})\end{array}$} & \multirow[t]{2}{*}{ bt } & 0.705 & 92.4 & 1.56 & \multirow{2}{*}{$114 \pm 6$} \\
\hline & & 0.718 & 92.7 & 1.56 & \\
\hline Ap-03 & bt & 2.30 & 96.1 & 5.24 & $113+6$ \\
\hline$(\mathrm{GrH})$ & & 2.43 & 96.7 & 5.24 & $113 \pm 6$ \\
\hline Gdp-04 & $\mathrm{hb}$ & 0.149 & 72.0 & 0.39 & $005+50$ \\
\hline$(\mathrm{GdK})$ & & 0.161 & 72.0 & 0.39 & $99.5 \pm 0.0$ \\
\hline Gdp-GSJ & bt & 2.81 & 80.8 & 6.36 & $10+6$ \\
\hline (GdK) & & 2.81 & 83.3 & 6.34 & $110 \pm 6$ \\
\hline Dikes intruding & into the $c$ & taclasite zor & & & \\
\hline Gdp-05 & $\mathrm{hb}$ & 0.097 & 58.2 & 0.25 & $981+25$ \\
\hline$(\mathrm{GdK})$ & & 0.099 & 56.8 & 0.25 & \\
\hline
\end{tabular}

These, together with the limited duration of the activity of the HFZ, suggest that the fault activity gradually changed from mylonitization to cataclasis. Crush zones existing in one outcrop of mylonite near the cataclasite zone tend to confirm this theory. Our findings support the theory that the HFZ experienced a brittle-plastic transition during its activity. Reconstructing this phenomenon should provide clues about the development of fault zones and the occurrence of earthquakes in brittle-plastic transition zones.

Acknowledgments. We thank Mr. K. Watanabe and Mr. J. Miyazaki for topographical map preparation. We also thank Associate Professors S. Koshiya and Y. Ohtomo for their careful reviews. This study is a part of a Comprehensive research program on flow and slip processes in and below seismogenic region sponsored by Ministry of Education, Culture, Sports, Science and Technology of Japan.

\section{References}

Dodson, M. H. and E. McClelland-Brown, Isotopic and palaeomagnetic evidence for rates of cooling, uplift and erosion, Geol. Soc. London Mem., 10, 315-325, 1985.

Geological Survey of Japan, Geological map of Japan, 1:1,000,000 (3rd Ed.), 1992.

Henley, R. W. and A. J. Ellis, Geothermal systems ancient and modern: a geochemical review, Earth Sci. Rev., 19, 1-50, 1983.

Iio, Y., Y. Kobayashi, and T. Tada., Large earthquakes initiate by the acceleration of slips on the downward extensions of seismogenic faults, Proc. Int. Symp. on Slip and Flow Processes in and below the Seismogenic Region, 407-411, 2001.

Kubo, K. and T. Yamamoto, Cretaceous intrusive rocks of Haramachi district, eastern margin of Abukuma Mountains-Petrography and $\mathrm{K}-\mathrm{Ar}$ age, J. Geol. Soc. Japan, 96, 731-743, 1990 (in Japanese with English abstract).

Kubo, K., Y. Yanagisawa, T. Yoshioka, T. Yamamoto, and F. Takizawa, Geology of the Haramachi and Omika district with Geological Sheet Map at 1:50,000, Geological Survey of Japan, 155p., 1990 (in Japanese with English abstract).

Linde, A. T., K. Suyehiro, S. Miura, I. S. Sacks, and A. Takagi, Episodic aseismic earthquake precursors, Nature, 334, 513-515, 1988.

Otsuki, K. and M. Ehiro, Cretaceous left-lateral faulting in Northeast Japan and its bearing on the origin of geologic structure of Japan, J. Geol. Soc. Japan, 98, 1097-1112, 1992 (in Japanese with English abstract).

Rutter, E. H., On the nomenclature of mode of failure transitions in rocks, Tectonophys., 122, 381-387, 1986.

Schmid, S. M., Microfabric studies as indicators of deformation mechanisms and flow laws operative in mountain building, in Mountain Building Processes, edited by K. Hsu, pp. 95-110, Academic Press, 1982.

Sendo, T., On the granitic rocks of Mt. Otakine and its adjacent districts in the Abukuma massif, Japan, Sci. Rep. Tohoku Univ. Third Series, 6, 57-167, 1958 .

Shibata, K. and S. Uchiumi, K-Ar ages on hornblendes from granitic rocks in the southern Abukuma Plateau, J. Min., Pet. and Eco. Geol., 78, 405410, 1983 (in Japanese with English abstract).

Shigematsu, N., Dynamic recrystallization in deformed plagioclase during progressive shear deformation, Tectonophys., 305, 437-452, 1999.

Shigematsu, N. and H. Tanaka, Dislocation creep of fine-grained recrystallized plagioclase under low temperature conditions, J. Struct. Geol., 22, 65-79, 2000.

Shigematsu, N. and H. Yamagishi, Quartz microstructures and deformation conditions in the eastern Hatagawa shear zone, NE Japan, Island Arc, 11, 45-60, 2002.

Shigematsu, N., K. Fujimoto, T. Ohtani, T. Tomita, and K. Omura, Plastic 
deformation and fracturing: a case study in the Hatagawa Fault Zone, Proc. Int. Symp. on Slip and Flow Processes in and below the Seismogenic Region, 265-272, 2001.

Sibson, R. H., Earthquake faulting as a structural process, J. Struct. Geol., 11, 1-14, 1989.

Steiger, R. H. and E. Jäger, Subcommission on geochronology: Convention on the use of decay constants in geo- and cosmochronology, Earth Planet. Sci. Lett., 36, 359-362, 1977.

Takagi, H., K. Goto, and N. Shigematsu, Ultramylonite bands derived from cataclasite and pseudotachylyte in granites, northeast Japan, J. Struct. Geol., 22, 1325-1339, 2000.

Thatcher, W., Episodic strain accumulation in Southern California, Science, 194, 691-695, 1976.

Watanabe, I., Y. Sotozaki, and M. Gorai, Geology of the north eastern border district of northern Abukuma plateau, Sci. Rep. Tokyo Ed. Univ., 2, 69 78, 1953 (in Japanese with English abstract).

White, S., The effects of strain on the microstructures, fabrics, and deformation mechanisms in quarzites, Phil. Trans. Royal Soc. London, $\mathbf{A 2 8 3}$ 69-86, 1976.

Yanagisawa, Y., T. Yamamoto, Y. Banno, T. Yoshioka, K. Kubo, and F. Takizawa, Geology of the Somanakamura district with Geological Sheet Map at 1:50,000, Geological Survey of Japan, 144 pp., 1996 (in Japanese with English abstract)

T. Tomita, T. Ohtani (e-mail: tomo-ohtani@aist.go.jp), N. Shigematsu, H. Tanaka, K. Fujimoto, Y. Kobayashi, Y. Miyashita, and K. Omura 